УДК 349.22

DOI https://doi.org/10.32837/pyuv.v1i4(29).402

Д. I. Cipoxa

orcid.org/0000-0003-2805-2278

кандидат юридичних наук, доиент,

доцент кафедри трудового права та права соціального забезпечення Київського національного університету ілені Тараса Шевченка

\title{
ПРОБЛЕМИ СПІВВІДНОШЕННЯ ПУБЛІЧНОЇ ТА КОРПОРАТИВНОЇ НОРМОТВОРЧОСТІ У ТРУДОВОМУ ПРАВІ УКРАЇНИ
}

Проблема удосконалення національного трудового законодавства вже багато років визначає спрямованість зусиль науковців і практиків. Не є секретом, що багато правових норм, які регулюють трудові відносини, приймалися за інших соціально-політичних умов, коли основним роботодавцем виступала держава, а правам і свободам учасників трудових відносин не приділялося стільки уваги, скільки приділяється сьогодні, коли поставлено амбітне завдання побудувати демократичну правову соціальну державу.

Удосконалення законів і підзаконних правових актів, якими регулюються трудові відносини, може бути успішним лише за умови, якщо розмежування компетенції суб'єктів нормотворчості буде побудовано на логічних несуперечливих і зрозумілих для правокористувача засадах. На жаль, реальна ситуація є принципово відмінною від бажаної: сьогодні сфера компетенції різних суб'єктів нормотворчості довільно тлумачиться у різних джерелах, що, скоріше, гальмує процес удосконалення трудового законодавства, ніж сприяє його вдосконаленню. Вказане зумовлюе актуальність та важливість співвідношення публічної та корпоративної нормотворчості у трудовому праві України.

Проблеми визначення сутності загальної та локальної нормотворчості розглядали у своï роботах Л.І. Антонова, Н.О. Брілліантова, С.В. Венедіктов, Т.А. Занфірова, М.I. Іншин, I. С. Кириленко, I.A. Красюк, С.С. Лукаш, P.А. Майданник, Н.О.Мельничук, О.О. Момоток, В.В. Панченко, П.М. Рабінович, В.В. Форманюк, Є.О. Харитонов, О.М. Ярошенко та інші науковці. Однак треба зауважити, що у науці трудового права вказані питання розглядалися переважно у контексті вирішення інших дослідницьких завдань, що зумовлюе необхідність більш детального аналізу співвідношення публічної і корпоративної нормотворчості.

Мета статті полягає у визначенні кола компетенції суб'єктів публічної і корпоративної нормотворчості і здійснення розмежування їх повноважень у досліджуваній сфері.

Закономірно, що чільне місце серед суб'єктів нормотворчості, котрі представляють політичну волю та законні інтереси Української держави, посідає Президент України, який є главою держави і виступає від іï імені, гарантує державний суверенітет і територіальну цілісність України, додержання Конституції України, прав і свобод людини і громадянина.

У юридичній науці існують різні класифікації повноважень Президента України. Так, одні вітчизняні правознавці виділяють повноваження глави держави у сфері представництва та зовнішньої політики, державного управління, військового керівництва, законодавства, судової галузі, громадянства, нагород, надзвичайних повноважень $[1$, с. 8]. На думку інших учених, повноваження Президента України можна поділити на такі групи: державне будівництво, нормотворча діяльність, забезпечення конституційної законності, повноваження в галузі оборони і національної безпеки, реалізація гарантій щодо забезпечення прав і свобод громадянина, зовнішня політика i міжнародні відносини, нагородна політика [2, с. 441]. Існують й інші класифікації повноважень Президента України.

Очевидним, на нашу думку, є і те, що роль нормотворчої діяльності Президента України та іiї результатів, втілених у відповідних правових актах глави держави, його законодавчих ініціативах тощо, набуває особливої важливості. Адже у конституційно-правових реаліях сьогодення Президент України видає правові акти, насамперед укази, які мають доленосне значення для подальшого розвитку та удосконалення державного будівництва та правотворення, здійснення правових реформ, а також видає в межах своєї компетенції інші документи (доручення, директиви тощо), реалізація яких передбачає удосконалення системи національного законодавства, в тому числі й у сфері праці.

Відповідно до положень ч. 1 ст. 106 Конституції України Президент України здійснює низку повноважень, за допомогою яких він реалізує свої основні завдання та функції як глава держави. Серед цих повноважень слід вирізняти представницькі, установчі, програмні, безпекові й оборонні, зовнішньополітичні, контрольні, арбітражні, інституційні, кадрові та інші. Усі ці види 
повноважень не можуть бути реалізованими без нормотворчості Президента України. Саме ці види повноважень і визначають зміст нормотворчої діяльності Президента України.

Погоджуємося з твердженням, що за своєю сутністю нормотворчість Президента України є юридичною діяльністю щодо втілення політичної волі глави держави у правових актах відповідної юридичної сили, легітимною формою реалізації його конституційних завдань, функцій і повноважень. Тобто нормотворчість Президента України та її результати є юридичним вираженням реалізації його владних повноважень. Зміст нормотворчості Президента України визначається предметом правового регулювання його правових актів, тобто видами повноважень глави держави, реалізація яких здійснюється через видання, скасування відповідних правових актів чи внесення змін до них [3, с. 20$]$.

Таким чином, нормотворчість Президента України можна визначити як самостійний вид юридичної діяльності, зміст якої полягає у прийнятті, скасуванні та удосконаленні правових актів відповідної юридичної сили у порядку, встановленому чинним законодавством.

Відповідно до ст. 75 Конституції України єдиним органом законодавчої влади в Україні є парламент - Верховна Рада України. Конституція України присвячує компетенції Верховної Ради самостійну статтю (ст. 85), що складається із 36 пунктів. Але вона не містить вичерпного переліку повноважень українського парламенту. Відповідно, як з погляду важливості, так і об'ємності стрижнем компетенції Верховної Ради є повноваження, які пов'язуються з реалізацією законодавчої функції. До них належить: внесення змін до Конституції в межах і порядку, передбачених розділом XIII Основного Закону, та прийняття законів.

Згідно з фундаментальними положеннями теорії конституційного (державного) права до парламентських прерогатив належать: прийняття законів, структуроутворююча і бюджетна сфери, парламентський контроль. Важливість і об’ємність компетенції парламентів зумовлена їх соціальним призначенням як представницьких органів народу, через які народ опосередковано здійснює владу, що йому належить.

Проте сучасний парламент майже цілком втратив право законодавчої ініціативи. Акти, які він ухвалює, розробляються та виносяться, головним чином, урядом: міністерствами, відомствами, департаментами та іншими центральними органами. Таким чином, парламент поступово перетворюється фактично з органу законодавчого на орган законостверджуючий.

Послаблення ролі парламенту в законодавчій діяльності виявляється в безперервному зростанні ролі делегованого законодавства, що передбачає встановлення правових норм тим чи іншим виконавчим суб'єктом в порядку, визначеному законодавством держави. 3 одного боку, правотворчі функції стабільно виконуються в окремих сферах державного управління, а з іншого - ці функції не властиві цим органам через їх безпосереднє призначення. Отже, втрачено не тільки суверенний характер парламентського законодавства, але й сама законодавча прерогатива певною мірою перейшла до адміністративного апарату. Питома вага парламентських актів у системі правових норм різко скоротилась, а їх застосування та тлумачення знаходяться в прямій залежності від адміністрації. Законопроекти виробляються в адміністративному апараті, а парламент отримує їх вже в готовому вигляді.

Відтак, незважаючи на те, що з ускладненням функцій держави значно збільшилися обсяги законодавчої діяльності парламенту, центром нормотворчості поступово стає уряд, що, на думку Н.Ф. Лати, є виправданим, оскільки не всі складні питання сучасного суспільства, з позиції вченої, повинні розглядатися парламентом, оскільки є ситуації, коли рішення доцільно передати на більш низький рівень, як того вимагають норми, які регулюють компетенцію правотворчих органів. Наявність нормотворчості органів виконавчої влади зумовлена також і великим обсягом суспільних відносин, які потребують свого нормативного закріплення, внаслідок чого і відбулася передача частини правотворчих повноважень від Верховної Ради України іншим суб'єктам нормотворчості [4, с. 21].

Відповідно до ст. 113 Конституції України Кабінет Міністрів України є вищим органом у системі органів виконавчої влади. Тоді як ст. 114 Основного Закону України передбачає існування центральних органів виконавчої влади (міністерств), а ст. 118 визначає місцеві державні адміністрації як місцеві органи виконавчої влади.

Статтею 117 Конституції України передбачено, що Кабінет Міністрів України у межах своєї компетенції видає постанови і розпорядження, які є обов'язковими до виконання. Акти Кабінету Міністрів, що мають нормативний характер, видаються у формі постанов. Акти з оперативних, організаційно-розпорядчих та інших питань, які не мають нормативного характеру, видаються у формі розпоряджень.

Окрім Уряду, до виконавчої гілки влади належать державні адміністрації, які також мають право на видання нормативно-правових актів [5, с. 23]. Відповідно до Закону України «Про місцеві державні адміністрації» такими актами є розпорядження голів державних адміністрацій.

Міністерства, державні комітети, інші відомства, які є центральними органами виконавчої 
влади, керують дорученими їм галузями управління. Їх повноваження в сфері видання нормативних актів визначені законами, актами Президента та Уряду. Зазвичай міністерства, що являють собою органи одноособового керівництва, видають накази та інструкції, а державні комітети як колегіальні органи - постанови. Нормативний характер мають зазвичай інструкції та постанови [6, с. 312].

Окреме місце серед даного виду займає нормотворчість органів місцевого самоврядування, як в аспекті реалізації власних, так і щодо делегованих повноважень.

Так, органи місцевого самоврядування є однією $з$ головних підвалин будь-якого демократичного режиму, тому існування зазначених органів, наділених реальними повноваженнями, може забезпечити ефективне і близьке до громадянина управління. Відтак органи публічної влади, що наближені до населення, можуть бути як державними, так і муніципальними. Цей висновок пов'язаний з розумінням муніципальної природи цих органів не за їхньою назвою, а за характером повноважень. Визначальними $є$ не формальноюридичний критерії щодо віднесення органу до того чи іншого рівня публічної влади, а його фактичні, насамперед компетенційні характеристики.

Так, відповідно до ст. 3 Європейської Хартії місцевого самоврядування [7] місцеве самоврядування означає право і спроможність органів місцевого самоврядування в межах закону здійснювати регулювання та управління суттєвою часткою публічних справ, під власну відповідальність, в інтересах місцевого населення. Це право здійснюється радами або зборами, члени яких вільно обираються таємним голосуванням на основі прямого, рівного, загального виборчого права i які можуть мати підзвітні їм виконавчі органи.

Головні повноваження і функції органів місцевого самоврядування визначаються Конституцією або законом. Однак це положення не перешкоджає наділенню органів місцевого самоврядування повноваженнями і функціями для спеціальних цілей відповідно до закону. Органи місцевого самоврядування в межах закону мають повне право вільно вирішувати будь-яке питання, яке не вилучене зі сфери їхньої компетенції і вирішення якого не доручене жодному іншому органу.

Зрештою, нормотворчість органів місцевого самоврядування примикає до нормотворчості державних органів і водночас утворює особливий, відокремлений від держави вид нормотворчої діяльності. Право створювати і приймати нормативно-правові акти (рішення) надається представницьким органам місцевого самоврядування і посадовим особам муніципальних утворень міста, селища, села. Органи місцевого самоврядування (наприклад, районних у містах рад) утворюють- ся населенням для вирішення завдань місцевого значення, їх рішення діють у суворо визначених територіальних рамках.

На відміну від публічної нормотворчості, нормотворчість комерційних корпорацій полягає у виданні корпоративних норм, спрямованих на регулювання питань життя самих корпоративних учасників і на деталізацію, конкретизацію законодавчих розпоряджень (наприклад, інструкція про порядок провадження претензійної та позовної роботи - корпоративний акт, який регулює порядок пред'явлення претензій на конкретному підприємстві та який деталізує і конкретизує законодавчі положення). Між тим, нормотворення корпорацій включає й розробку статутів підприємств, які є актами установчого характеру, а також положень, правил, посадових інструкцій тощо. Усі корпоративні акти підлягають реєстрації i (або) затвердженню державними та корпоративними органами. Їхня дія, яка має правове значення, значно зросла в сучасних умовах вільного розвитку і діяльності комерційних організацій [8, с. 77].

Як наслідок, корпоративну нормотворчість можна визначити як таку, що існує в рамках повноважень та протікає в певному організаційному порядку, діяльність з прийняття, зміни та відміни корпоративних норм [9, с. 27]. При цьому в контексті нормотворчості суб'єктів трудового права ми можемо визначити корпоративною нормотворчістю у сфері трудового права як чітко регламентована нормами права та корпоративними актами діяльність суб’єктів трудового права, що існує в рамках повноважень та протікає в певному організаційному порядку та полягає у прийнятті, зміні та скасуванні нормативних актів індивідуальної та колективної дії для забезпечення розвитку та ефективного протікання трудових відносин.

Зокрема, нормотворчість роботодавців та їх об’єднань полягає у самостійному чи за участю трудового колективу (інших суб'єктів трудового права), створенні та прийнятті локальних нормативних актів, в яких закріплюються права та обов'язки учасників трудових правовідносин. Саме у зв'язку з цим дослідники у сфері трудового права за суб'єктним критерієм всі акти локальної нормотворчості поділяють на акти самостійної нормотворчість роботодавця, акти, ухвалені роботодавцем 3 врахуванням думки виборного представницького органу трудового колективу працівників або за згодою з ним, та акти спільної нормотворчості роботодавця і трудового колективу $[10$, с. $150-151,157]$. Нормотворчість роботодавців виражається в їх установчих документах, які є актами фундаторського характеру, а також у положеннях, правилах, посадових інструкціях тощо. Також необхідно відзначити, що локальні нормативні акти, які мають самостійний характер, видаються зазвичай не самим роботодавцем, 
а його уповноваженими органами та мають підзаконний характер.

Нормотворчість громадських об'єднань (організацій) виражається у розробці та прийнятті статутів, у яких визначаються права і обов'язки об’єднання або організації, порядок їхньої діяльності, реорганізації та ліквідації. Нормативні акти видаються також їх керівниками. Такі нормативні рішення мають силу остільки, оскільки відповідають чинним нормативно-правовим актам, виданим державою, і приймаються в межах повноважень фундаторів і керівництва об'єднання. На відміну від правотворчих функцій державних органів, нормотворча діяльність громадських організацій зазвичай виключає самостійне прийняття ними норм права.

Однією із історично зумовлених, специфічних громадських організацій працівників виступають професійні. Метою їх діяльності є здійснення представництва та захисту трудових, соціально-економічних прав та інтересів своїх членів. Нормотворча діяльність професійних спілок полягає, зокрема, в створенні та прийнятті статутів, в яких закріплюються права та обов'язки об'єднання (організаціі), порядок їх діяльності, реорганізації та ліквідації, а також спільній їх нормотворчій діяльності із роботодавцями. Крім того, проекти нормативно-правових актів, які стосуються регулювання трудових, соціальних, економічних відносин, розглядаються органами виконавчої влади та органами місцевого самоврядування 3 урахуванням думки відповідних профспілок, об'єднань профспілок (ч. 3 ст. 21 Закону України «Про професійні спілки, їх права та гарантії діяльності»).

Крім того, слід згадати такого суб'єкта нормотворчості, як трудовий колектив. Щодо його ролі та значення у сучасних умовах точаться численні дискусії, дослідження яких потребує здійснення окремих наукових розвідок. Разом 3 тим можна стверджувати, що нормотворчість трудових колективів (державних і комерційних підприємств, установ, організацій) спрямована на розвиток норм трудового права, дія яких поширюються лише на відносини одного підприємства, установи або організації, де їх прийнято. Вона виступає зазвичай у вигляді нормативних угод, що містять обов'язкові до виконання правові розпорядження. Такою нормативною угодою $є$ колективний договір - консолідований акт у галузі праці, що регулює трудові, соціально-економічні та виробничі відносини між роботодавцем і трудовим колективом на підприємстві, в установі, організації, незалежно від форми власності, відомчої приналежності та кількості робітників; поширюється на всіх робітників незалежно від того, чи $€$ вони членами профспілки, i $є$ обов’язковим як для керівництва (власника), так і для робітників. Він підлягає обов'язковому обговоренню і схваленню трудовим колективом на загальних зборах (конференціях) робітників даного підприємства, установи, організації.

Завдяки колективним договорам і угодам надається можливість членам громадянського суспільства, роботодавцям і працівникам самостійно встановлювати права і обов'язки, обмежувати втручання держави у сферу, що становить приватний інтерес. Колективні договори здатні поліпшити норми законів і підзаконних актів, заповнити прогалини в законодавстві, орієнтувати законодавця на удосконалення та впорядкування норм трудового права.

Отже, поряд із державною або централізованою нормотворчістю суб'єктів трудового права існує й корпоративна нормотворчість, суб'єктами якої виступають роботодавці та їх об'єднання, професійні спілки та їх об'єднання, трудові колективи. Можна констатувати, що корпоративні норми заповнюють прогалини в нормативній системі права і мають допоміжний характер. Предметом їх регулювання є відносини усередині колективу (встановлення умов праці, заохочення працівників, порядок застосування заходів відповідальності тощо). Корпоративні норми права являються результатом правової спеціалізації, встановлюються $з$ метою конкретизації та деталізації, обліку своєрідності конкретних відносин.

\section{Jimepamypa}

1. Агафонов С.А. Інститут президента у системі державної влади України : автореф. дис. юрид. наук. Київ, 2003. 20 с.

2. Сырых В.М. Теория государства и права : учеб. для вузов. Москва, 2006. 704 с.,

3. Нормотворча діяльність Президента України та їі нормопроектне забезпечення: питання теорії і практики / О.В. Скрипнюк, В.Л. Федоренко, Ю.Г. Барабаш, Я.О. Берназюк та ін. Київ : НАДУ, 2011. 344 с

4. Лата Н.Ф. Адміністративно-правове регулювання нормотворчої діяльності органів виконавчої влади : дис. ... канд. юрид. наук : 12.00.07. Київ, 2004. 198 с.

5. Стьопіна Н.О., Грушкевич Т.В., Монастирський Д.А. Нормотворення в юридичних клініках : навч. посіб. / за наук. ред. В.М. Олуйка. Хмельницький : ПП Петришин Г.М., 2006. 156 с.

6. Проблемы общей теории права и государства : учеб. для вузов / под общ. ред. В.С. Нерсесянц. Москва : Норма, 2008. 832 с.

7. Свропейська Хартія місцевого самоврядування (м. Страсбург, 15 жовтня 1985 року). URL: https://zakon.rada.gov.ua/laws/show/994_036 (дата звернення 11.12.2019).

8. Плавич С.В. Теоретико-методологічні засади правотворчості : дис. ... канд. юрид. наук : 12.00.01. Київ : 2009. 215 с.

9. Маргулис М.А. Нормотворчество корпоративных объединений в области спорта : дис. ... канд. юрид. наук : 12.00.01. Москва, 2006. 186 с.

10. Лебедев В.М. Современное трудовое право (Опыт трудоправового компаративизма). Книга первая / В.М. Лебедев, Е.Р. Воронкова, В.Г. Мельникова; под ред. В.М. Лебедева. Москва : Статут, 2007. 301 с. 


\section{Анотація}

Сіроха Д. I. Проблеми співвідношення публічної та корпоративної нормотворчості у трудовому праві України. - Стаття.

У статті на підставі аналізу доктринальних джерел і положень правових актів розглянуто сутність публічної і корпоративної нормотворчості в трудовому праві України. Автором з'ясовано, що проблема удосконалення національного трудового законодавства кілька десятиліть визначає спрямованість зусиль науковців і практиків. Багато правових норм, які регулюють трудові відносини, приймалися за умов, коли основним роботодавцем виступала держава, а правам і свободам учасників трудових відносин не приділялося достатньої уваги. Удосконалення правових актів, якими регулюються трудові відносини, потребує розмежування компетенції суб'єктів нормотворчості. Мета статті полягає у визначенні кола компетенції суб’єктів публічної і корпоративної нормотворчості і здійснення розмежування їх повноважень у досліджуваній сфері. У статті розглянуто особливості нормотворчості Президента України, Верховної Ради України, Кабінету Міністрів України, центральних органів виконавчоі влади, органів місцевого самоврядування, роботодавців та їх об'єднань, професійних спілок, трудових колективів. Охарактеризовано властивості публічної та корпоративної нормотворчості з урахуванням відмінностей між ними. 3'ясовано, що завдяки колективним договорам i угодам надається можливість членам громадянського суспільства, роботодавцям і працівникам самостійно встановлювати права і обов'язки, обмежувати втручання держави у сферу, що становить приватний інтерес. Зроблено висновок, що поряд із державною або централізованою нормотворчістю суб'єктів трудового права існує й корпоративна нормотворчість, суб'єктами якої виступають роботодавці та їх об'єднання, професійні спілки та їх об'єднання, трудові колективи. Автор констатує, що корпоративні норми заповнюють прогалини в нормативній системі права і мають допоміжний характер. Предметом регулювання корпоративних норм є відносини усередині колективу (встановлення умов праці, заохочення працівників, порядок застосування заходів відповідальності тощо). Корпоративні норми права є результатом правової спеціалізації, встановлюються 3 метою конкретизації та деталізації, обліку своєрідності конкретних відносин.

Ключові слова: публічна нормотворчість, корпоративна нормотворчість, суб'єкти нормотворчості, трудові відносини, корпоративні норми.

\section{Summary}

Sirokha D. I. Problems of public relations and corporate rule-making in the labor law of Ukraine. Article.

The scientific article considers on the basis of the analysis of doctrinal sources and provisions of legal acts the essence of public and corporate rulemaking in the labor law of Ukraine is considered. The author found that the problem of improving national labor legislation for several decades determines the focus of the efforts of scientists and practitioners. Some legal norms governing labor relations were adopted when the state was the main employer, and the rights and freedoms of participants in labor relations were not given sufficient attention. The improvement of legal acts that regulate labor relations requires the delimitation of the competence of the subjects of rule-making. The purpose of the article is to determine the terms of reference of subjects of public and corporate rulemaking and the implementation of the delimitation of their powers in the studied area. The article discusses the features of the rulemaking of the President of Ukraine, the Verkhovna Rada of Ukraine, the Cabinet of Ministers of Ukraine, central executive bodies, local governments, employers and their associations, trade unions, labor collectives. Properties are characterized by public and corporate rulemaking, taking into account the differences between them. It's been agreed that, apart from collective agreements and pleasures, members of the huge suspension can be invited, robot teachers and practitioners to independently gain rights and obligations, to separate the power from the sphere, to establish private interests. The conclusion is made that, along with state or centralized rulemaking of subjects of labor law, there is also corporate rulemaking, the subjects of which are employers and their associations, trade unions and associations, and labor collectives. The author states that corporate norms fill the gaps in the regulatory system of law and are auxiliary in nature. The subject of regulation of corporate norms is the relationship within the work collective. Such relations cover the establishment of working conditions, employee incentives, the procedure for applying liability measures, etc. Corporate rules of law are the result of legal specialization, are established with the aim of concretization and detail, taking into account the uniqueness of specific relations.

Key words: public rulemaking, corporate rulemaking, rulemaking entities, labor relations, corporate norms. 